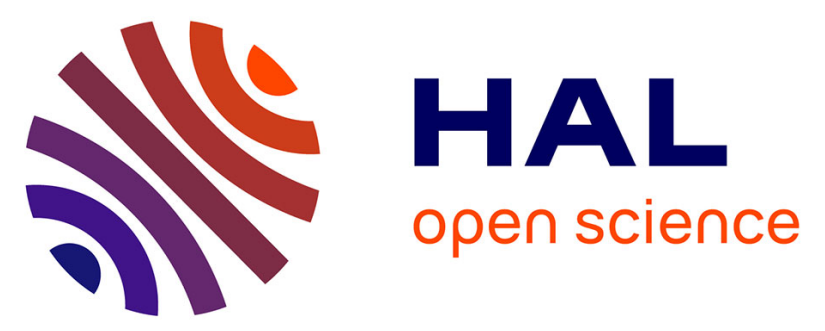

\title{
Laccase induction by synthetic dyes in Pycnoporus sanguineus and their possible use for sugar cane bagasse delignification
}

\author{
Christian Hernández, Anne Marie Farnet da Silva, Fabio Ziarelli, Isabelle \\ Perraud-Gaime, Beatriz Gutierrez-Rivera, José Antonio García-Pérez, Enrique \\ Alarcón
}

\section{To cite this version:}

Christian Hernández, Anne Marie Farnet da Silva, Fabio Ziarelli, Isabelle Perraud-Gaime, Beatriz Gutierrez-Rivera, et al.. Laccase induction by synthetic dyes in Pycnoporus sanguineus and their possible use for sugar cane bagasse delignification. Applied Microbiology and Biotechnology, 2017, 101 (3), pp.1189-1201. 10.1007/s00253-016-7890-0 . hal-02069482

\section{HAL Id: hal-02069482 https://hal.science/hal-02069482}

Submitted on 15 Mar 2019

HAL is a multi-disciplinary open access archive for the deposit and dissemination of scientific research documents, whether they are published or not. The documents may come from teaching and research institutions in France or abroad, or from public or private research centers.
L'archive ouverte pluridisciplinaire HAL, est destinée au dépôt et à la diffusion de documents scientifiques de niveau recherche, publiés ou non, émanant des établissements d'enseignement et de recherche français ou étrangers, des laboratoires publics ou privés. 


\title{
Laccase induction by synthetic dyes in Pycnoporus sanguineus and their possible use for sugar cane bagasse delignification
}

\author{
Christian Hernández ${ }^{1}$ Anne-Marie Farnet Da Silva ${ }^{2}$ - Fabio Ziarelli ${ }^{3}$. \\ Isabelle Perraud-Gaime ${ }^{4}$ - Beatriz Gutiérrez-Rivera ${ }^{5}$. José Antonio García-Pérez ${ }^{6}$. \\ Enrique Alarcón ${ }^{1}$ (i)
}

\begin{abstract}
The use of synthetic dyes for laccase induction in vivo has been scarcely explored. We characterized the effect of adding different synthetic dyes to liquid cultures of Pycnoporus sanguineus on laccase production. We found that carminic acid (CA) can induce $722 \%$ and alizarin yellow $317 \%$ more laccase than control does, and they promoted better fungal biomass development in liquid cultures. Aniline blue and crystal violet did not show such positive effect. CA and alizarin yellow were degraded up to $95 \%$ during $P$. sanguineus culturing (12 days). With this basis, CA was selected as the best inducer and used to evaluate the induction of laccase on solid-state fermentation (SSF), using
\end{abstract}

Enrique Alarcón

enalarcon@uv.mx

1 Instituto de Biotecnología y Ecología Aplicada (INBIOTECA), Universidad Veracruzana, Av. de las Culturas Veracruzanas No. 101, Col. Emiliano Zapata, C.P. 910910 Xalapa, Veracruz, Mexico

2 Equipe Systèmes Microbiens, IMBE, UMR CNRS 7263, IRD 237, Aix Marseille Université, Avignon Université, Campus de l'Etoile, Site de St. Jérôme, Marseille, France

3 Faculté des Sciences et Techniques de Saint-Jérôme, Spectropole, Aix Marseille Université, PO box 512, Avenue Escadrille Normandie Niémen, 13397 Marseille cedex 20, France

4 Equipe Ecotechnologies et Bioremediation, IMBE, UMR CNRS 7263, IRD 237, Aix Marseille Université, Avignon Université, Campus de l'Etoile, Site de St. Jérôme, Marseille, France

5 Instituto Tecnológico Superior de Tierra Blanca (ITSTB), Tierra Blanca, Veracruz, Mexico

6 Facultad de Biología, Universidad Veracruzana, Cto. Gonzalo Aguirre Beltrán sn, Col. Emiliano Zapata, C.P. 91090 Xalapa, Veracruz, Mexico sugarcane bagasse ( $\mathrm{SCB}$ ) as substrate, in an attempt to reach selective delignification. We found that laccase induction occurred in SSF, and a slight inhibition of cellulase production was observed when CA was added to the substrate; also, a transformation of SCB under SSF was followed by the ${ }^{13} \mathrm{C}$ cross polarization magic angle spinning (CPMAS) solid-state nuclear magnetic resonance (NMR). Results showed that $P$. sanguineus can selectively delignify $\mathrm{SCB}$, decreasing aromatic $\mathrm{C}$ compounds by $32.67 \%$ in 16 days; $O$-alkyl C region (polysaccharides) was degraded less than $2 \%$; delignification values were not correlated with laccase activities. Cellulosecrystallinity index was increased by $27.24 \%$ in absence of CA and $15.94 \%$ when $0.01 \mathrm{mM}$ of CA was added to SCB; this dye also inhibits the production of fungal biomass in SSF (measured as alkyl $\mathrm{C}$ gain). We conclude that $\mathrm{CA}$ is a good inducer of laccase in liquid media, and that $P$. sanguineus is a fungus with high potential for biomass delignification.

Keywords Alizarin yellow · Carminic acid · Endoglucanase · ${ }^{13} \mathrm{C}$ CPMAS solid-state NMR · Cellulose crystallinity

\section{Introduction}

Laccases (benzenediol/oxygen oxidoreductase, EC 1.10.3.2) are enzymes with the capacity to degrade lignin and other phenolic compounds, like mono-, di-, and polyphenols, aminophenols, methoxyphenols, aromatic amines, and ascorbic acid (Ding et al. 2014). Recently, laccases have been proposed as biocatalyst for many industrial and bioremediation processes, including biobleaching (Zheng et al. 2012; Monteiro and De Carvalho 1998), azo dyes degradation for wastewater treatment (Chhabra et al. 2015; Kanagaraj et al. 2015; Teerapatsakul et al. 2007, 2008; Junghanns et al. 2008; Vanhulle et al. 2007), herbicide degradation (Pizzul et al. 
2009; Jolivalt et al. 1999), petroleum-derivate phenols degradation (Vargas and Ramírez 2002), and biomass delignification (Rico et al. 2015; Ryu et al. 2013).

For industrial applications, vast amounts of protein are extremely important (Songulashvili et al. 2015); thus, many studies have focused in enhancing the production of this enzyme with different organisms. Laccases are produced by bacteria (Dhiman and Shirkot 2015; Galai et al. 2009), filamentous ascomycetes (Cázares-García et al. 2013), and brownrotting basidiomycetes (An et al. 2015); however, white-rot fungi are the desired producers because of the high yields obtained, and the high catalytic laccases produced (Viswanath et al. 2014; Ramírez-Cavazos et al. 2014). The production of laccase by culturing white-rot fungi can be done in liquid media (Songulashvili et al. 2006, 2015) and in solidstate fermentation (Karp et al. 2012); in both systems, the use of inducers can enhance the production of laccase (Hernández et al. 2015, Khammuang et al. 2013; Meza et al. 2005).

Inducer compounds must be abundant and not expensive to be used at large scale; industrial wastes meet these assumptions. Many metals (e.g., cupper, manganese, and cadmium) phenolic compounds (Mann et al. 2015) and synthetic dyes can induce laccase production in fungi (Kuhar and Papinutti 2014), and much of them are discarded in wastewaters. Phenolic dyes are of special interest due to textile industries that generate a large amount of wastewater $\left(120 \mathrm{~m}^{3} /\right.$ Ton fiber produced) enriched with synthetic dyes (1100-1300 Hazen units; Anjaneyulu et al. 2005), which generate environmental problems, e.g., when the azo dyes are degraded in anaerobic conditions, they can generate carcinogenic aromatic amines (Arslan et al. 2013).

Besides the degradation of many phenolic dyes that has been proven via laccase catalysis (Kanagaraj et al. 2015; Younes et al. 2011; Bayramoglu et al. 2012), there are few studies that evaluate in vivo induction of laccase by synthetic dyes (Table 1). The induction of high laccase production in vivo by synthetic dyes can be very useful for lignocellulose pretreatment, in order to enhance lignin decay and, indirectly, decrease the cellulose crystallinity index (CI). Achieving the reduction of lignin and $\mathrm{CI}$, cellulose and hemicellulose are more easily hydrolyzed by enzymes (Yu et al. 2014; Yoshida et al. 2008), which are very important for bioethanol production.

This work aimed to test the induction of laccase with four synthetic/phenolic dyes: carminic acid, alizarin yellow, aniline blue, and violet crystal at different concentrations in liquid media and, subsequently, utilize the best inducer to enhance the production of laccase in solid-state fermentation (SSF). Carminic acid is an anthraquinone dye which is naturally present in the cochineal insect Dactylopius coccus (Eisner et al. 1980) and has been used since pre-Hispanic time as a textile and ceramic dye in Mexico. On the other hand, alizarin yellow is a common azo dye used in textile industry, such as dye cotton, nylon, and silk (Bowes et al. 1991), and as other azo dyes, which are potentially hazardous for the environment because of their toxicity (Bae et al. 2006), mutagenic (Freeman et al. 1996) and carcinogenic (Hildenbrand et al. 1999). The other two tested dyes were aniline blue, a common dye used for wool and cotton staining, and crystal violet, which has uses in paper and ink industries.

The substrate (sugar cane bagasse) modifications were evaluated by ${ }^{13} \mathrm{C}$ cross-polarization magic angle spinning (CPMAS) nuclear magnetic resonance (NMR), in order to determine if the addition of dyes to lignocellulose promotes a decay in lignin amount and CI values.

\section{Materials and methods}

\section{Strain and inoculum}

Pycnoporus sanguineus strain was isolated from the sugarcane fields of Jalcomulco, Veracruz, México $\left(19^{\circ} 20^{\prime} 00^{\prime \prime} \mathrm{N}\right.$, $\left.96^{\circ} 46^{\prime} 00^{\prime \prime} \mathrm{W}\right)$, cultured on a potato-dextrose-agar medium

Table 1 Phenolic dyes used for laccase induction or for decoloration test in vivo with fungi

\begin{tabular}{llll}
\hline Dye & Type & Fungi & Reference \\
\hline Reactive black 5 & Azo dye & Leptosphaerulina sp. & Copete et al. (2015) \\
Amaranth, reactive black 5, cibacron brilliant yellow & Azo dyes & Trametes versicolor & Champagne and Ramsay (2005) \\
Amido black & Azo dye & Pleurotus pulmonarius & Zilly et al. (2002) \\
Congo red & Azo dye & Pleurotus pulmonarius & Zilly et al. (2002) \\
Bromophenol blue & Triphenylmethane dye & Pycnoporus sanguineus & Pointing and Vrijmoed (2000) \\
Malachite green & Triphenylmethane dye & Pycnoporus sanguineus & Pointing and Vrijmoed (2000) \\
Violet crystal & Triphenylmethane dye & Trametes maxima & Hernández-Luna et al. (2008) \\
Amaranth & Azo dye & Trametes versicolor & Swamy and Ramsay (1999) \\
Textile wastewater & Mixture of colorants & Pycnoporus sp. SYBC-L3 & Lui et al. (2012) \\
Remazol brilliant blue reactive & Anthraquinonic dye & Trametes villosa & Hernández-Luna et al. (2008) \\
\hline
\end{tabular}


(PDA), stored at $4{ }^{\circ} \mathrm{C}$, and reactivated in Petri dishes with PDA medium at $30{ }^{\circ} \mathrm{C}$ for 7 days prior to the experiment. The collected fungus was identified by Ramírez-Guillén F., a classical taxonomy expert, and deposited at XAL Herbarium (INECOL A.C., Xalapa, Mexico) as F. Ramírez-Guillén 932. In addition, this fungal strain was identified by sequencing ITS 1 region, compared with sequences in GenBank, and the DNA sequence obtained was deposited in GenBank under the accession number KR013138.

\section{Experimental design and culture conditions for liquid cultures}

In order to determine whether the different aromatic dyes induced laccase production in $P$. sanguineus, a bifactorial experiment was designed. Different synthetic dyes (Fig. S1 in the Supplementary Material) were tested to induce laccase production in liquid cultures of $P$. sanguineus: carminic acid, alizarin yellow, aniline blue, and violet crystal. The dyes were added, at three different concentrations $(0,0.01,0.02$, and $0.03 \mathrm{mM}$ ), to $150 \mathrm{ml}$ of culture medium (basal medium; Eggert et al. 1996) with the following composition (per liter): $1 \mathrm{~g}$ of $\mathrm{KH}_{2} \mathrm{PO}_{4}, 0.26 \mathrm{~g}$ of $\mathrm{NaH}_{2} \mathrm{PO}_{4}, 0.317 \mathrm{~g}$ of $\left(\mathrm{NH}_{4}\right)_{2} \mathrm{SO}_{4}$, $0.5 \mathrm{~g}$ of $\mathrm{MgSO}_{4} 7 \mathrm{H}_{2} \mathrm{O}, 0.5 \mathrm{mg}$ of $\mathrm{CuSO}_{4}, 74 \mathrm{mg}$ of $\mathrm{CaCl}_{2}$, $6 \mathrm{mg}$ of $\mathrm{ZnSO}_{4}, 5 \mathrm{mg}$ of $\mathrm{FeSO}_{4}, 5 \mathrm{mg}$ of $\mathrm{MnSO}_{4}, 1 \mathrm{mg}$ of $\mathrm{CoCl}_{2}$, supplemented with carboxy-methyl cellulose as carbon source (2\%) and yeast extract $\left(1 \mathrm{~g} \mathrm{~L}^{-1}\right)$ as nutrient source; $\mathrm{pH}$ was adjusted to 6 .

The cultures were performed in quadruplicate, in plastic containers of $500 \mathrm{ml}$. Each experimental replicate was inoculated with two plugs of agar-containing mycelium ( 6 days old) and were incubated in darkness at $30^{\circ} \mathrm{C}$ in an environmental chamber (Binder, GmbH; Tuttlingen, Germany). Samplings were performed each 3 days for 12 days of incubation to test laccase activity $\left(\mathrm{U} \mathrm{L}^{-1}\right)$; meanwhile, biomass production (mg of dry mass) and dye degradation (\%) were determined at the end of the incubation time.

\section{Analytical methods for liquid cultures}

Laccase activity in liquid cultures was estimated according to Criquet et al. (1999). Twenty microliters of a solution of $5 \mathrm{mM}$ syringaldazine was added to $980 \mu \mathrm{L}$ of the culture sample. The oxidation kinetics from syringaldazine to quinone was followed at $525 \mathrm{~nm}\left(\varepsilon=65,000 \mathrm{M}^{-1} \mathrm{~cm}^{-1}\right)$ at $37^{\circ} \mathrm{C}$ for $90 \mathrm{~s}$. The activity was expressed as $\mu$ moles of quinone formed from syringaldazine per minute $(U)$ per one liter of culture $\left(\mathrm{U} \mathrm{L}^{-1}\right)$.

Fungal biomass from liquid cultures was calculated at the end of the experiment: cultures were vacuum-filtered and recovered biomass was dried at $60{ }^{\circ} \mathrm{C}$ by $48 \mathrm{~h}$. Biomass weight was estimated by the gravimetric method and was reported as milligrams of dry mass (mg.DM ${ }^{-1}$ ). Aromatic dye degradation was estimated according to linear models obtained from known concentrations ( 0 to $0.03 \mathrm{mM}$ ) and the absorbance measured at the wavelength of the main peaks (nm) in the visible light spectrum (aniline blue: 595, $610 \mathrm{~nm}$; violet crystal: 588, $592 \mathrm{~nm}$; carminic acid $494 \mathrm{~nm}$; alizarine yellow: 358, $363 \mathrm{~nm}$ ). Absorbance was quantified with a UV spectrophotometer and transformed into $\mathrm{mM}$ according to linear models (Table 2).

\section{Experimental design and culture conditions for solid-state fermentation}

The conditions that induced the highest laccase activity were used for the second experimental phase. Because the lowest CA concentration in liquid cultures reach the highest laccase activity, different concentrations of carminic acid were tested in solid-state fermentation (SSF): 0.00, 0.003, 0.006, and $0.01 \mathrm{mM}$; a volume of basal medium enriched with yeast extract and carminic acid was added to $50 \mathrm{~g}$ of pre-dried sugar cane bagasse (SCB) until a final humidity of $80 \% \mathrm{v} / \mathrm{w}$. The wet SCB was deposited into poly-paper plastic bags and sterilized by autoclaving $\left(120{ }^{\circ} \mathrm{C}: 1.5 \mathrm{~atm}\right)$ for $20 \mathrm{~min}$. After cooling, three-agar squares $0.25 \mathrm{~cm}^{2}$ in size with reactivated mycelium (7 days of culture) were used as inoculum. The mesocosms were incubated in darkness at $30{ }^{\circ} \mathrm{C}$ in an environmental chamber (Binder, GmbH; Tuttlingen, Germany). Each treatment was replicated four times, and samplings to determine laccase and endoglucanase activities were done each for 4 days during 16 days from expendable replicates; consequently, a total of 80 mesocosms (4 replicates $\times 4$ carminic acid concentrations $\times 5$ sampling dates) were set up. SCB samples were analyzed by ${ }^{13} \mathrm{C}$ CPMAS NMR methodology, in order to determine the substrate modification by P. sanguineus.

Enzyme activity was normalized with the protein and biomass values. Protein was determined according to Bradford (1976).

\section{Analytical methods for SSF phase}

Enzymatic activities were calculated from concentrated protein extracts, obtained according to Criquet et al. (1999): $5 \mathrm{~g}$ of $\mathrm{SSB}$ (fresh weight) were added to $100 \mathrm{ml}$ of $0.2 \mathrm{M} \mathrm{CaCl}_{2}$

Table 2 Models utilized for phenolic dyes degradation

\begin{tabular}{ll}
\hline Model equation & $\mathrm{R}^{2}$ \\
\hline [Aniline blue, peak $595 \mathrm{~nm}]=(\gamma 595 \mathrm{~nm}+0.46) / 1.93$ & 0.82 \\
[Aniline blue, peak $610 \mathrm{~nm}]=(\gamma 610 \mathrm{~nm}+0.643) / 2.22$ & 0.90 \\
[Violet crystal, peak $588 \mathrm{~nm}]=(\gamma 588 \mathrm{~nm}-2.813) / 1.75$ & 0.85 \\
[Violet crystal, peak $592 \mathrm{~nm}]=(\gamma 592 \mathrm{~nm}-2.19) / 1.98$ & 0.90 \\
[Alizarin yellow, peak 358 nm] $=(\gamma 358 \mathrm{~nm}-0.913) / 1.24$ & 0.93 \\
[Alizarin yellow, peak 363 nm] $=(\gamma 358 \mathrm{~nm}-0.94) / 1.105$ & 0.92 \\
[Carminic acid, peak 494 nm] $=(\gamma 494 \mathrm{~nm}-0.176) / 0.81$ & 0.99 \\
\hline
\end{tabular}


buffer added with Tween $800.05 \%$, and $6 \mathrm{~g}$ of polyvinylpyrrolidone (PVP) stirred per $1 \mathrm{~h}$ at $\sim 220 \mathrm{rpm}$ and then filtered with $0.2 \mu \mathrm{m}$ cellulose filters. Fifty milliliters of the crude extract was dialyzed within cellulose tubular membranes (Sigma-Aldrich; St. Louis, USA) and polyethylene glycol (PEG-8000) overnight at $4{ }^{\circ} \mathrm{C}$; concentrated proteins were recovery in one volume of $0.2 \mathrm{M}$ sodium phosphate buffer with $\mathrm{pH} 6$ and were used for enzymatic determinations.

The reaction mixture of laccase determination was as follows: $100 \mu \mathrm{l}$ of protein extract, $880 \mu \mathrm{l}$ of $0.2 \mathrm{M}$ sodium phosphate buffer $\mathrm{pH}$, and $20 \mu \mathrm{l}$ of syringaldazine $5 \mathrm{mM}$. Endoglucanase activity was estimated according to Ghose (1987), measuring simple sugars released from carboxymethyl cellulose (CMC, $2 \%$ ), by the method of dinitrosalicilic acid (DNS). The reaction mixture for endoglucanase estimation was as follows: $250 \mu \mathrm{l}$ of protein extract was mixed with $250 \mu \mathrm{l}$ of CMC $2 \%$; the reaction was incubated in a water bath at $50^{\circ} \mathrm{C}$ for $1 \mathrm{~h}$. The reaction was stopped with $500 \mu \mathrm{l}$ of DNS reagent, boiled for $5 \mathrm{~min}$, and immediately cooled in icy water for $10 \mathrm{~min}$. The reaction mixture was diluted with $5 \mathrm{ml}$ of $\mathrm{dH}_{2} \mathrm{O}$ prior spectrophotometer quantification $(540 \mathrm{~nm})$. Absorbance was transformed into grams per liter of glucose by comparison with a standard glucose curve $\left(\mathrm{g} \mathrm{L}^{-1}\right)$. In the case of SSF, both enzymatic activities were reported as $\mu$ moles of quinone formed from syringaldazine per minute (U) per $g$ of dry mass $\left(\mathrm{U} \mathrm{g} \mathrm{DM}^{-1}\right)$ of SCB.

\section{Substrate modifications}

Changes in the chemical composition of SCB were followed via ${ }^{13} \mathrm{C}$ CPMAS NMR in a Bruker Advance DSX $400 \mathrm{MHz}$ spectrometer (Bruker, Madison, WI, USA). One hundred milligrams of dried and ground SCB was placed in a zirconium rotor and spun at the magic angle $\left(54.44^{\circ}\right)$ at $10 \mathrm{KHz}$. The ${ }^{13} \mathrm{C}$ CPMAS NMR technique was performed with a ramped ${ }^{1} \mathrm{H}$ pulse during a contact time of $3 \mathrm{~ms}$ and with ${ }^{1} \mathrm{H}$ decoupling during the acquisition time to improve the resolution. Recording $4 \mathrm{~K}$ transients with a recycling delay of $2 \mathrm{~s}$ represented standard conditions to obtain a good signal-to-noise ratio.

Deconvolution of NMR spectra was performed using the DmFit software (Massiot et al. 2002). Specifically, regions of NMR spectra were utilized as indicators of chemical shifts in SCB: alkyl C (0-45 ppm) and carboxyl C (160-190 ppm) were related to fungal biomass production since they can be assigned to membrane phospholipids and since only very weak signals were observed in the sugar cane bagasse. Polysaccharides content were estimated measuring the $O$-alkyl C signal (45-110 ppm) and the content in aromatic C compounds measuring the signal between 110 and $160 \mathrm{ppm}$. Cellulose crystallinity index was calculated according to Park et al. (2010), by separating the $\mathrm{C}_{4}$ region of the spectrum into crystalline and amorphous peaks, and calculated by dividing the total area of the crystalline peak ( 87 to $93 \mathrm{ppm}$ ) by the total area assigned to the $C_{4}$ peak (80-93 ppm). In addition, changes in aromatic $\mathrm{C}$ region were evaluated according to Hallac et al. (2009), measuring the decrease of $p$ hydroxyphenyl (162-157 ppm), aromatic quaternary C (160-123 ppm), and aromatic tertiary C (123-103 ppm) signals.

\section{Statistical analysis}

Data of laccase activity and biomass production was analyzed by two-way ANOVA $(\alpha=0.05)$, in order to identify if the different dyes added to the medium or their concentrations had significant effects on these variables; when ANOVA was significant, a post hoc Fisher LSD analysis was made. In addition, Pearson product-moment correlation coefficient $(r)$ between laccase activity, biomass production, and percentage of dyes degradation was done. All the analyses were done in the software STATISTICA 7 (StatSoft Inc. 2004).

\section{Results}

\section{The effects of aromatic dyes on biomass and laccase production in liquid cultures}

Two-way ANOVA showed that the type of dye added to liquid media affects the amount of biomass produced $\left(F_{2}=6.10\right.$; $P=0.006$ ); meanwhile, dye concentration had no significant effects $\left(F_{2}=1.29 ; P=0.29\right)$, but the interaction between dye type and dye concentration was significant $\left(F_{4}=4.31\right.$; $P=0.007$ ). Treatments with aniline blue (whatever the concentration), alizarin yellow $(0.01 \mathrm{mM})$, and carminic acid $(0.03 \mathrm{mM})$ were those that produced more fungal biomass (Fig. 1). More precisely, the production of biomass increased with carminic acid concentrations while an inhibiting effect was found for alzarine yellow concentrations of 0.02 and $0.03 \mathrm{mM}$. Moreover, fungal biomass production was positively correlated with laccase production only in cultures with carminic acid $(r=0.66 ; P=0.001)$.

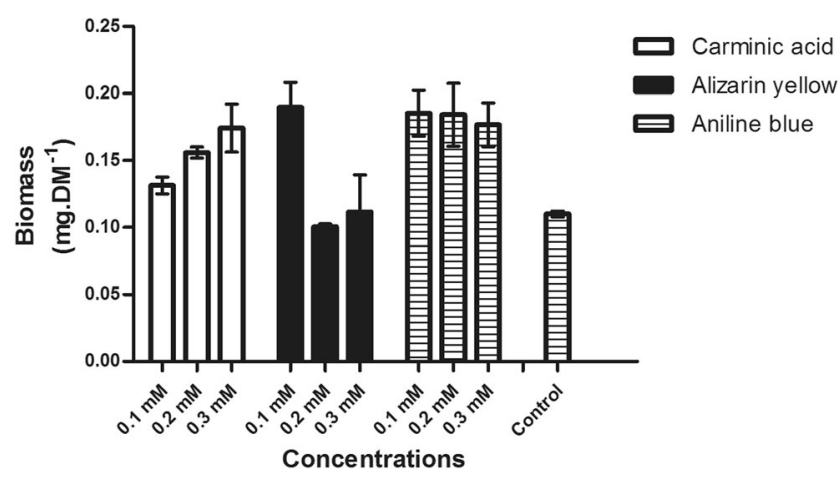

Fig. 1 Biomass production in liquid media enriched with phenolic dyes at different concentrations. Bars indicate the mean and whiskers the standard error 
According to our ANOVA results, the addition of different aromatic dyes to culture medium of $P$. sanguineus affects laccase production $(F=79.07 ; P<0.001)$; meanwhile, the concentration was not significant $(F=2.28 ; P=0.11)$ as well as the interaction between the type of dye and dye concentration $(F=1.31 ; P=0.27)$. Cultures with carminic acid showed the highest (Fig. 2) total laccase activities (i.e., $\left.0.01 \mathrm{mM}=273.65 \pm 90.72 \mathrm{U} \mathrm{L}^{-1}\right)$, followed by alizarin yellow $\left(0.01 \mathrm{mM}=120.85 \pm 81.51 \mathrm{U} \mathrm{L}^{-1}\right)$ and control $\left(37.8 \pm 12.25 \mathrm{U} \mathrm{L}^{-1}\right)$. Cultures with aniline blue showed lower values $\left(0.01 \mathrm{mM}=34.46 \pm 10.16 \mathrm{U} \mathrm{L}^{-1}\right)$. No laccase activity nor fungal development was observed in cultures with violet crystal (Fig. 2).

Because the effect of the dyes on laccase production was compromised by the effect of the dyes on the biomass development (Fig. 1), total laccase activity was normalized with the amount of total protein (specific activity), and with the amount of total biomass. The higher the concentration of CA, the fewer the activity of laccase ( $\mathrm{U} g$ protein $^{-1} \mathrm{~g}$ biomass ${ }^{-}$; Table 3), with the exception of the control. With this basis, we found that carminic acid at the concentration of $0.01 \mathrm{mM}$ was the best inducer of laccase (Table 3), and we determine to use it in the following tests (SSF).

\section{Dye degradation}

Carminic acid and alizarin yellow were degraded in $P$. sanguineus liquid cultures (Table 4). Carminic acid was degraded above of $92 \%$ in all concentrations tested, and alizarin yellow by $97 \%$ in cultures with an initial concentration of $0.01 \mathrm{mM}, 48 \%$ in cultures with $0.02 \mathrm{mM}$, and $60 \%$ in cultures with $0.03 \mathrm{mM}$. This is consistent with the fact that laccase activity was weaker for alizarin yellow concentrations of 0.02 and $0.03 \mathrm{mM}$. Dye degradation was positively correlated with laccase activity (carminic acid $r=0.91 P<0.0001$; alizarin yellow $r=0.64, P=0.02$ ).

\section{Enzyme production in SSF}

Enzyme activities in SSF showed maximum values after 12 days for endoglucanase (Fig. 3a) and after 8 days for laccase (Fig. 3b). ANOVA results indicate that the amount of carminic acid added to SCB affects the endoglucanase activity $\left(F_{3}=10.96 ; P=0.004\right)$. According to Fisher LSD post hoc test, cultures without carminic acid had the highest endoglucanase activity (1116.45 $\pm 127.12 \mathrm{U} \mathrm{g} \mathrm{DM}^{-1}$; Fig. 3a); meanwhile, the higher the carminic acid, the lower the endoglucanase activity was observed (Fig. 3a). On the other hand, laccase activity was detected at 4 and 8 days of culture, and laccase increased when carminic acid was added. Treatments with carminic acid showed higher laccase activity, with an average of $1.09 \pm 0.40 \mathrm{U} \mathrm{g} \mathrm{DM}^{-1}$, whatever the concentration of CA than control $\left(0.75 \pm 0.31 \mathrm{U} \mathrm{g} \mathrm{DM}^{-1}\right)$. Normalized laccase activity (U biomass ${ }^{-1}$; Table 5) corroborate that $\mathrm{CA}$ induces laccase production in SSF, in a range of 21.05 to $42 \%$ more than control, after 8 days of culture.
Fig. 2 Laccase activity $\left(\mathrm{U} \mathrm{L}^{-1}\right)$ kinetics of liquid cultures with different dyes addition, in concentration from 0 to $0.01 \mathrm{mM}$. Middle points indicate the mean and whiskers the standard error. a A red glucosidal hydroxyanthrapurin dye. $\mathbf{b}$ an azo-dye. $\mathbf{c}$ a trisulfonate dye. $\mathbf{d}$ treatment without dye
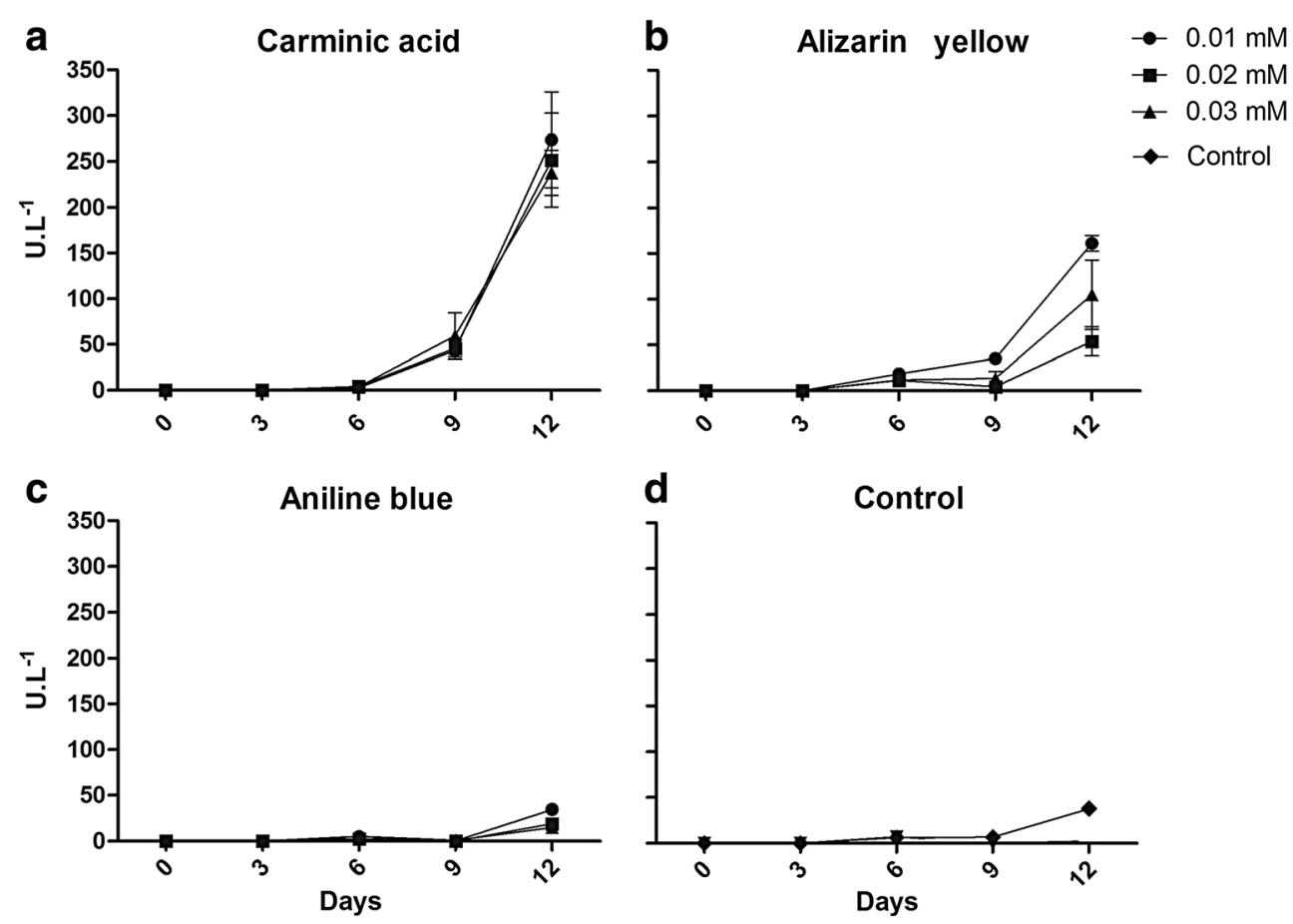
Table 3 Laccase total activity $\left(\mathrm{U} \mathrm{L}^{-1}\right)$, specific activity $\left(\mathrm{U} g\right.$ protein $\left.{ }^{-1}\right)$, and normalized activity $\left(\mathrm{U} g\right.$ protein $\left.{ }^{-1} \mathrm{~g} \mathrm{biomass}^{-1}\right)$. Obtained with the addition of carminic acid and alizarin yellow in liquid cultures. Values are mean and SD; $n=4$

\begin{tabular}{llllll}
\hline & $\mathrm{U} \mathrm{L}^{-1}$ & Protein, $\mathrm{g} \mathrm{L}^{-1}$ & $\mathrm{U} \mathrm{g}^{-1}$ & Biomass, g DM $^{-1}$ & $\mathrm{Ug} \mathrm{protein}^{-1} \mathrm{~g} \mathrm{biomass}^{-1}$ \\
\hline Control & 37.8 & $0.33 \pm 0.02$ & $114.54 \pm 44.9$ & $0.11 \pm 0.004$ & $1041.32 \pm 368$ \\
Carminic acid 0.01 & $273.65 \pm 90.7$ & $0.35 \pm 0.006$ & $781.85 \pm 197.0$ & $0.13 \pm 0.01$ & $6014.29 \pm 2242$ \\
Carminic acid 0.02 & $251.43 \pm 102.3$ & $0.34 \pm 0.020$ & $739.50 \pm 297.8$ & $0.15 \pm 0.008$ & $4930.00 \pm 1930$ \\
Carminic acid 0.03 & $237.69 \pm 49.0$ & $0.33 \pm 0.03$ & $720.27 \pm 241.3$ & $0.17 \pm 0.03$ & $4236.90 \pm 2340$ \\
Alizarin yellow 0.01 & $161.14 \pm 15.1$ & $0.36 \pm 0.02$ & $447.61 \pm 70.19$ & $0.18 \pm 0.03$ & $2486.73 \pm 452$ \\
Alizarin yellow 0.02 & $53.9 \pm 31.7$ & $0.46 \pm 0.01$ & $117.17 \pm 71.8$ & $0.1 \pm 0.004$ & $1171.74 \pm 696$ \\
Alizarin yellow 0.03 & $104.85 \pm 75.8$ & $0.46 \pm 0.01$ & $227.93 \pm 158.5$ & $0.11 \pm 0.05$ & $2072.13 \pm 3521$ \\
\hline
\end{tabular}

\section{NMR chemical shifts in SSF}

${ }^{13} \mathrm{C}$ CPMAS NMR showed variations in the chemical composition of sugarcane bagasse under biological pretreatment with P. sanguineus and at different concentrations of carminic acid over time (after 16 days under SSF; Fig. 4). Cellulose crystallinity index (CI) increased in all the treatments; SCB had an initial CI ratio of 0.34 and increased $27.34 \%$ in the control. When carminic acid was added, the increment in CI was lower (Table 6).

Changes in the chemical composition of SCB were mainly observed for the aromatic $\mathrm{C}$ region, which indicates changes in SCB lignin fraction. However, the reduction of these values was higher in control and when $0.003 \mathrm{mM}$ of carminic acid was added, reaching a reduction in aromatic $\mathrm{C}$ signals of 32.67 and $30.65 \%$, respectively. Treatments with $0.006 \mathrm{mM}$ of carminic acid showed a decrease of $16.33 \%$; meanwhile, when $0.01 \mathrm{mM}$ were added, the aromatic region only decreased by $1.95 \%$. However, aromatic quaternary $\mathrm{C}$ diminish its signal by $17.60 \% .{ }^{13} \mathrm{C}$ CPMAS NMR analysis also showed that SCB's lignin had very little $p$-hydroxyphenyl $(162-157 \mathrm{ppm})$ radicals, and that the peaks obtained for aromatic $\mathrm{C}$ region corresponded mainly to aromatic quaternary $\mathrm{C}$ $(160-123 \mathrm{ppm})$ and aromatic tertiary C (123-103 ppm; Table 6).

Carboxylic $\mathrm{C}$ and alkyl $\mathrm{C}$ regions of the spectra were related to fungal biomass development (membrane phospholipid production); the increase in those regions was lower when
Table 4 Degradation of the dyes used as inducers in liquid media (first experimental phase)

\begin{tabular}{lllll}
\hline Dye & $\begin{array}{l}\text { Wavelength } \\
\text { measured, } \mathrm{nm}\end{array}$ & $\begin{array}{l}\text { Initial } \\
\text { concentration, } \mathrm{mM}\end{array}$ & $\begin{array}{l}\text { Final } \\
\text { concentration, } \mathrm{mM}\end{array}$ & $\begin{array}{l}\text { Degradation } \\
\text { percentage }\end{array}$ \\
\hline Carminic acid & 494 & 0.01 & 0.0004 & $95.97 \pm 3.78$ \\
Carminic acid & 494 & 0.02 & 0.001 & $92.57 \pm 1.27$ \\
Carminic acid & 494 & 0.03 & 0.002 & $92.48 \pm 0.79$ \\
Alizarin yellow & 358 & 0.01 & 0.0004 & $95.88 \pm 14.15$ \\
Alizarin yellow & 363 & 0.01 & 0 & $100 \pm 0.5$ \\
Alizarin yellow & 358 & 0.02 & 0.010 & $49.15 \pm 0.57$ \\
Alizarin yellow & 363 & 0.02 & 0.010 & $46.85 \pm 0.82$ \\
Alizarin yellow & 358 & 0.03 & 0.011 & $61 \pm 2.59$ \\
Alizarin yellow & 363 & 0.03 & 0.012 & $58 \pm 4.18$ \\
Aniline blue & 595 & 0.01 & 0.01 & 0 \\
Aniline blue & 610 & 0.01 & 0.01 & 0 \\
Aniline blue & 595 & 0.02 & 0.03 & 0 \\
Aniline blue & 610 & 0.02 & 0.02 & 0 \\
Aniline blue & 595 & 0.03 & 0.031 & 0 \\
Aniline blue & 610 & 0.03 & 0.029 & 0 \\
Violet crystal & 588 & 0.01 & 0.01 & 0 \\
Violet crystal & 592 & 0.01 & 0.01 & 0 \\
Violet crystal & 588 & 0.02 & 0.015 & 0 \\
Violet crystal & 592 & 0.02 & 0.016 & 0 \\
Violet crystal & 588 & 0.03 & 0.03 & 0.03 \\
Violet crystal & 592 & 0.03 & & 0 \\
\hline & & & 0 & 0 \\
\hline
\end{tabular}


a

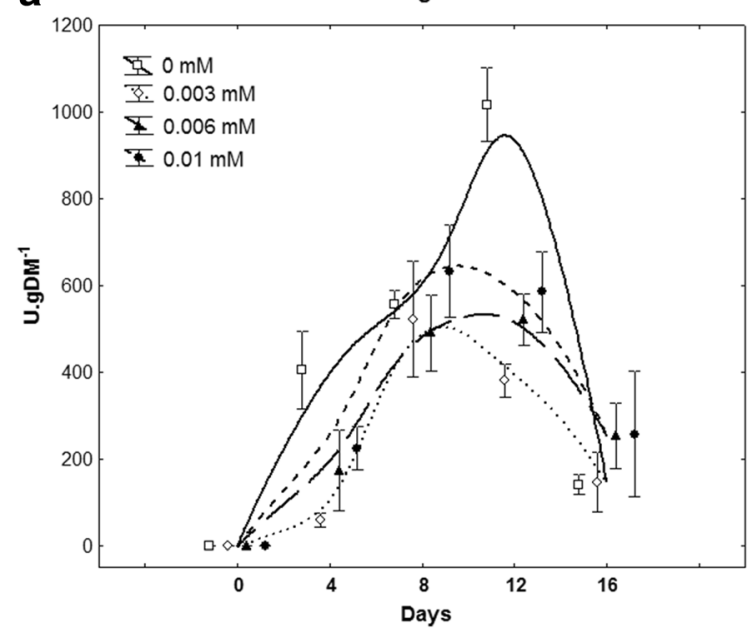

b

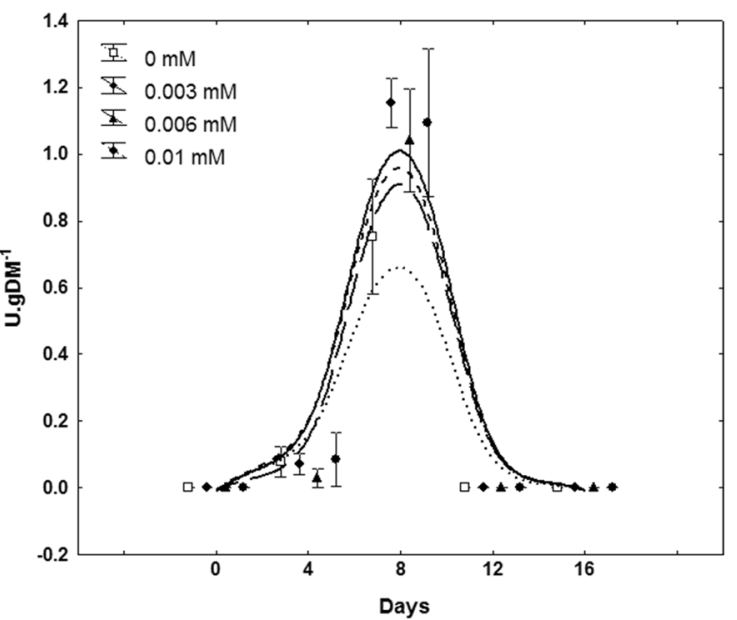

Fig. 3 Enzymatic activities observed in SSF phase. a Endoglucanase activity, highest activity was registered in treatments without carminic acid at day 12. b Laccase activity was only registered after 4 and 8 days. Middle points indicate the mean and whiskers the standard error

carminic acid was added to SCB compared to the control (Table 6), which indicated negative effects of carminic acid in biomass production, in SSF. On the other hand, the polysaccharide content ( $O$-alkyl $\mathrm{C}$ ) was almost unchanged in all treatments (decreased less than $2 \%$ ) and no differential effects were observed in treatments with and without carminic acid.

\section{Discussion}

\section{Liquid cultures}

We observed that carminic acid and alizarin yellow can enhance total laccase by 722 and $317 \%$ more than the control, respectively, in liquid cultures with $P$. sanguineus. In an early report, Korniłłowicz-Kowalska and Rybczyńska (2014) indicated that carminic acid can induce the production of other phenoloxidases in Bjerkandera adusta CCBAS 930 like Mn peroxidase and horseradish peroxidase, and that the production of these enzymes its accompanied with a degradation of carminic acid and Poly R-478.

Low concentrations of alizarin yellow also increase the laccase activity but in less proportion that CA does. This study contributes to the knowledge on this field, proving that alizarin yellow can induce laccase production and that azo dyes and anthraquinonic dyes can be degraded in liquid cultures of P. sanguineus.
Biomass production was also modified by the addition of dyes into culture medium: aniline blue (all concentrations), carminic acid $(0.03 \mathrm{mM})$, and alizarin yellow $(0.01 \mathrm{mM})$ enhanced the production of biomass in liquid cultures of $P$. sanguineus. The increased biomass production in cultures with these dyes could indicate that $P$. sanguineus can use them as nutrient sources, i.e., alizarin yellow and aniline blue can function as nitrogen and sulfur sources (Dave et al. 2015); however, the nutrimental role of carminic acid is still unclear. Biomass production was positive correlated with alizarin yellow and carminic acid degradation, and with laccase production.

$P$. sanguineus does not produce either Mn peroxidase $(\mathrm{MnP})$ or lignin peroxidase (LiP) (Pointing and Vrijmoed 2000; Eggert et al. 1997), but it is considered as a good laccase producer (Pointing et al. 2000); thus, the decoloration capacity is probably related to the laccase production observed. Laccase-mediated dye degradation has been previously reported for carminic acid in agar plates and with purified enzymes from Pleutorus ostreatus, Kuehneromyces mutabilis, Trametes versicolor, and Cerrena unicolor (Cho et al. 1999, 2007).

In addition, alizarin yellow degradation in cultures of $P$. sanguineus reached values up to $95 \%$ (with an initial concentration of $0.01 \mathrm{mM}$ ), similar to other technological methods, e.g., laser-induced photocatalytic degradation (Hayat et al. 2010) or hybrid processes like iron-carbon
Table 5 Fungal biomass indicators (COOH, alkyl-C) in SSF after 8 days of culture. Their relationship with laccase production (U $\Sigma \mathrm{COOH}$ alkyl- $\mathrm{C}^{-1}$ )

\begin{tabular}{lccccc}
\hline & COOH & Alkyl-C & $\mathrm{UgDM}^{-1}$ & Biomass $(\Sigma C O O$, alkyl-C) & U biomass $^{-1}$ \\
\hline Control & 7.92 & 32.14 & 0.75206154 & 40.06 & 0.019 \\
Carminic acid 0.003 & 8.54 & 34.06 & 1.15373077 & 42.60 & 0.027 \\
Carminic acid 0.006 & 8.91 & 35.98 & 1.04263077 & 44.89 & 0.023 \\
Carminic acid 0.01 & 9.04 & 35.40 & 1.09390769 & 44.44 & 0.025 \\
\hline
\end{tabular}




Fig. 4 Specters obtained from ${ }^{13} \mathrm{C}$ CPMAS NMR analysis. a Cultures without carminic acid. $\mathbf{c}$ Cultures with $0.003 \mathrm{mM}$ of carminic acid. b Cultures with $0.006 \mathrm{mM}$ of carminic acid. d Cultures with $0.01 \mathrm{mM}$ of carminic acid. Signals of different carbon functional groups are indicated in the basis of the specters, and the square maximizes the aromatic $\mathrm{C}$ region. Note that $\mathrm{C} 4$ has two signal peaks, which corresponds to crystalline and amorphous forms

microelectrolysis combined to aerobic bio-contact oxidation (Liang et al. 2012). This azo dye has been degraded in vitro by chloroperoxidases of Caldariomyces fumago (Li et al. 2013), but we did not find previous reports of laccase-mediated decolorization of alizarin yellow. However, in this study, we found a high correlation with alizarin yellow decolorization and laccase production in vivo. Laccase has been utilized in many studies for azo dyes degradation in vitro (Abadulla et al. 2000; Pointing and Vrijmoed 2000; Rodriguez et al. 1999). The other tested dyes (aniline blue and crystal violet) were not degraded in liquid cultures, and no laccase production was registered.

Thus, carminic acid was the stronger laccase inducer tested here in liquid cultures of $P$. sanguineus: It promoted higher laccase and biomass production than the other dyes and was degraded more than $95 \%$ at the end of incubation time (12 days); even if the induction mechanism is not clear, some anthraquinone-derived compounds could be involved in the induction of phenol-oxidases. For these reasons, this anthraquinone dye was selected for being utilized in solid-state fermentation, in an attempt to induce laccase activity and consequently depolymerize the lignin faction of sugar cane bagasse (SCB).

\section{Solid-state fermentation}

Many studies reported the induction of laccase in SSF using white-rot fungi, and most of them tested the effect of different carbon sources, nitrogen sources, the use of surfactants (e.g., Tween) and metal or organic inducers, like cooper and xylidine (El-Batal et al. 2015; Karp et al. 2015; Boran and Yeşilada 2011). However, only few have evaluated the effect of dye for ligninolytic enzymes induction. We found that, as well as in liquid cultures, carminic acid was able to enhance laccase production in SSF, compared to control treatments, even though induction was lower. In spite of that, laccases showed to have none or negative effect on the delignification with respect to control.

Usha et al. (2014) reported that bioabsorption of synthetic dyes such as remazol brilliant blue and remazol brilliant violet $5 \mathrm{R}$, onto lignocellulose (wheat bran and rice bran), and its further use for laccase and lignin peroxidase production was possible, using Stereum ostrea. Other studies reported that malachite green absorbed onto wheat bran could be used as solid substrate to produce lignin peroxidase from Fomes sclerodermeus (Papinutti et al. 2006). Remazol brilliant blue and remazol brilliant violet $5 \mathrm{R}$ are anthraquinone dyes, as well as carminic acid; thus, this work along with these previous reports showed evidence that anthraquinone dyes can be added onto lignocellulosic material, and this substrate can enhance phenol-oxidases production.

When carminic acid was added to sugarcane bagasse, cellulase activity decreased, which is positive as an attempt to reach selective delignification, and it aimed to reduce the lignin fraction and the cellulose crystallinity index, while preserving the carbohydrate fraction (Ramos 2003). Generally, when fungi are used, these characteristics can be achieved with high phenol-oxidase activities (e.g., laccase) and low cellulase activities, in order to reach a selective delignification (Dorado et al. 2001) useful to biomass pretreatments for bioethanol production. Some authors considered that P. sanguineus is capable of selective delignification (Gupta et al. 2011; Lomascolo et al. 2011), and it has been reported that this fungus can produce its own redox mediator which enhances lignin decay in the presence of laccase, i.e., 3hydroxyanthranilic acid (3-HAA; Eggert et al. 1996). This fungal metabolite can mediate the degradation of nonphenolic lignin structures by laccase (Eggert et al. 1996).

The enzymatic responses in SSF with or without carminic acid had to be considered together with chemical shifts in SCB composition measured by ${ }^{13} \mathrm{C}$ CPMAS NMR. We found that the main structural shifts in SSF were taking place in the aromatic $\mathrm{C}$ region. Other studies that used ${ }^{13} \mathrm{C}$ CPMAS NMR to evaluate lignocellulosic transformation (sorghum

Table 6 Chemical shifts in SCB after 16 days of culturing. Data are given in percentage of increment or decrement

\begin{tabular}{llllllll}
\hline Treatment & $\begin{array}{l}\text { Cellulose } \\
\text { crystallinity ratio }\end{array}$ & $\begin{array}{l}\text { COOH (organic } \\
\text { acids) }\end{array}$ & $\begin{array}{l}\text { Alkyl C } \\
\text { (lipids) }\end{array}$ & $\begin{array}{l}\text { O-alkyl C } \\
\text { (polysaccharides) }\end{array}$ & $\begin{array}{l}\text { Aromatic } \\
\text { C }\end{array}$ & $\begin{array}{l}\text { Aromatic } \\
\text { quaternary C }\end{array}$ & $\begin{array}{l}\text { Aromatic } \\
\text { tertiary C }\end{array}$ \\
\hline Control & $+27.24 \%$ & $+572.79 \%$ & $+2035.98 \%$ & $\mathrm{NC}$ & $-32.67 \%$ & $-25.89 \%$ & $-7.05 \%$ \\
$\begin{array}{c}\text { Carminic acid } \\
\quad 0.003 \mathrm{mM}\end{array}$ & $+18.74 \%$ & $+400.89 \%$ & $+1489.33 \%$ & $-1.94 \%$ & $-30.65 \%$ & $-34.82 \%$ & $-7.05 \%$ \\
$\begin{array}{c}\text { Carminic acid } \\
\quad 0.006 \mathrm{mM}\end{array}$ & $+15.94 \%$ & $+470.64 \%$ & $+1696.49 \%$ & $-0.94 \%$ & $-16.33 \%$ & $-27.00 \%$ & $-5.18 \%$ \\
$\begin{array}{c}\text { Carminic acid } \\
0.01 \mathrm{mM}\end{array}$ & $+15.94 \%$ & $+214.04 \%$ & $+936.99 \%$ & $-1.35 \%$ & $-1.95 \%$ & $-17.60 \%$ & $-5.57 \%$ \\
\hline
\end{tabular}

$N C$ no changes 
and wheat wastes), in solid-state cultures of white-rot fungi, concluded that the growth of such type of fungi mainly led to a decrease in aromatic C amount (Akin et al. 1996), which is similar to our observations.

The delignification yields obtained here are interesting when comparing with other studies, which used white-rot fungus in SSF. Delignification yields of $33 \%$ have been reported in SSF using Pleurotus ostreatus and a combination of ferulic acid and cooper sulfate as laccase inducers (Karp et al. 2015). Also, our results are similar to those obtained by Masayuki et al. (2005) using rice straw inoculated with either P. ostreatus (41\%), Phanerochaete chrysosporium (21\%), or Trametes versicolor (37\%). However, it should be noted that the incubation time in these experiments was longer (about 60 days) than that used here (16 days). Even if carminic acid induced more laccase production in SSF, we did not find higher delignification rates; indeed, surprisingly, when carminic acid was added, less of the aromatic $\mathrm{C}$ region was degraded. Dyes could be adsorbed by the solid substrate (Sen et al. 2016), reducing their availability to the fungi. This could reduce the laccase induction effect that we observed in liquid cultures, and thus the effect on lignin degradation was not evident in SSF.

We observed that the $O$-alkyl C region, which corresponds to polysaccharides, was slightly affected over time and decreased less than $2 \%$ in all treatments. This result is in accordance to Gupta et al. (2011) and Lomascolo et al. (2011), which suggested that $P$. sanguineus is a fungus with a selective action on lignin. Selectively delignification of SCB by $P$. sanguineus could be an efficient way of pretreatment, in order to enhance enzymatic hydrolysis in second-generation bioethanol production. This mainly because can diminish $32.67 \%$ of lignin, with less than $2 \%$ of carbohydrate losses.

Crystallinity index (CI) is another important issue to account in biomass pretreatments. Here, we observed that solid-state fermentation with $P$. sanguineus increases $27.24 \%$ the CI after 16 days, mainly when carminic acid was absence. The CI value indicates the relation between the amount of crystalline cellulose and amorphous cellulose (Park et al. 2010); when the aim is to hydrolyze cellulose with cellulases, it is desired to have low CI values because amorphous cellulose is more easily degraded by cellulases (Yu et al. 2014; Yoshida et al. 2008). When fungi degrade lignocellulose, generally the CI value increases (Howell et al. 2009), as we observed with $P$. sanguineus; however, when carminic acid was added, the increment of CI was lower than the controls. According to our results, the addition of carminic acid at low concentrations $(0.003 \mathrm{mM})$ in combination with $P$. sanguineus offers several advantages for SCB pretreatment, i.e., it induces the production of laccase and diminishes by $30.65 \%$ of aromatic compounds; the increment of CI was lower in this treatments $(18.79 \%)$ than the control $(27.24 \%)$ and partially avoids the biomass production.
In the basis of the results obtained, we can recommended the use of $P$. sanguineus for SCB selective delignification, even though it increased its CI value; also, carminic acid is a good inducer of laccase both in liquid cultures and in SSF. However, its use to enhance delignification could be limited because it affects biomass production. Further experiments could be design to avoid this limiting.

This study showed that the use of carminic acid and alizarin yellow, two important textile and industrial dyes, enhance the production of laccase better in liquid cultures of $P$. sanguineus than in SSF (carminic acid). Also, the use of $P$. sanguineus for SCB delignification could bring many advantages, as a rapid and efficient lignin decay with very few polysaccharides losses, even in the absence of inducers. When carminic acid was added to sugarcane bagasse, cellulase activity decreased, preserving the carbohydrate fraction and increasing the cellulose crystallinity index. Finally, we found that higher laccase amount does not necessary entails to higher delignification yields, biomass and redox mediators could have important roles in this process.

Acknowledgments The authors would like to thank to Mexican Consejo Nacional de Ciencia y Tecnología (CONACyT) for the Ph.D. scholarship of Hernández C, to ANUIES-CONACyT-ECOS-NORD (M13A02), Mexican and French government for financial, to Universidad Veracruzana (INBIOTECA), to Aix Marseille Université (IMBE, IRD and Spectropole) for technical support, and to the anonymous reviewers of this manuscript.

\section{Compliance with ethical standards}

Funding This study was funded by the Mexican Consejo Nacional de Ciencia y Tecnología (CONACyT) and the ANUIES-CONACyT-ECOSNORD Program (M13A02).

Conflict of interest The authors declare that they have no competing interests.

Human and animal rights and informed consent This article does not contain any studies with human participants or animals performed by any of the authors.

\section{References}

Abadulla E, Tzanov T, Costa S, Robra K, Cavaco-Paulo A, Gübitz GM (2000) Decolorization and detoxification of textile dyes with a laccase of Trametes hirsuta. Appl Environ Microb 66:3357-3362

Akin DE, Morrison WH III, Rigsby LL, Gamble GR, Sethuraman A, Eriksson KEL (1996) Biological delignification of plant components by the white-rot fungi Ceriporiosis subvermispora and Cyathus stercoreus. Anim Feed Sci Tech 63:305-321. doi:10. 1016/S0377-8401(96)00998-4

An H, Wei D, Xiao T (2015) Transcriptional profiles of laccase genes in the brown rot fungus Postia plancenta MAD-R-698. J Microbiol 53: 606-615. doi:10.1007/s12275-015-4705-4 
Anjaneyulu Y, Chary NS, Suman DS (2005) Decolourization of industrial effuents - available methods and emerging technologies: a review. Rev Environ Sci Biotech 4:245-273. doi:10.1007/s11157-0051246-z

Arslan M, Sayin S, Yilmaz M (2013) Removal of carcinogenic azo-dyes from water by new cyclodextrin-immobilized iron oxide magnetic nanoparticles. Water Air Soil Poll 224:1527. doi:10.1007/s11270$013-1527-z$

Bae J, Freeman HS, Dong S (2006) Influences of new azo dyes to the aquatic ecosystem. Fiber Polym 7:30-35. doi:10.1007/BF02933599

Bayramoglu GG, Gursel I, Yilmaz M, Arica MK (2012) Immobilization of laccase on itaconic acid grafted and $\mathrm{Cu}$ (II) ion chelated chitosan membrane for bioremediation of hazardous materials. J. Chem. Technol. Biotechnol. 87:530-539. doi:10.1002/jctb.2743

Boran F, Yeşilada O (2011) Enhanced production of laccase by fungi under solid substrate fermentation condition. Bioresources 6(4): 4404-4416

Bowes A, Collins S, Elliott S, Harris LT, Hazlett L, Methe E, Razak M, Subagiyo PY, Ballard MW (eds) (1991) Important early synthetic dyes: chemistry, constitution, date, properties. Conservation Analytical Laboratory, Smithsonian Institution, Washington, DC

Bradford MM (1976) A rapid and sensitive method for the quantitation of microgram quantities of protein utilizing the principle of protein-dye binding. Anal Biochem 72:248-252

Cázares-García SV, Vázquez-Garcidueñas Ma S, Vázquez-Marrufo G (2013) Structural and phylogenetic analysis of laccase from Trichoderma: a bioinformatics approach. PLoS One 8(1):e55295. doi:10.1371/journal.pone.0055295

Champagne P-P, Ramsay JA (2005) Contribution of manganese peroxidase and laccase to dye decoloration by Trametes versicolor. Appl Microbiol Biotechnol 69:276-285. doi:10.1007/s00253-005-1964-8

Chhabra M, Mishra S, Sreekrishnan TR (2015) Immobilized laccase mediated dye decolorization and transformation pathway of azo dye acid red 27. J Environ Health Sci Eng 13:38. doi:10.1186/s40201015-0192-0

Cho N, Park JM, Choi TH, Matuszewska A, Jaszek M, Grzywnowicz K, Malarczyk E, Trojanowski K, Leonowicz A (1999) The effects of wood rotting fungi and laccase on destaining of dyes and KP bleaching effluent. Korean J Wood Sci Technol 27(4):72-79

Cho H, Cho N, Jarosa-Wilkolazka A, Rogalski J, Leonowicz A, Shin Y, Ohga S (2007) Effect of fungal laccase and new mediators, acetovanillone and acetosyringone, on decolourization of dyes. J Fac Agr Kyushu Univ 52(2):275-280

Copete LS, Chanagá X, Barriuso J, López-Lucendo MF, Martínez MJ, Camarero S (2015) Identification and characterization of laccasetype multicooper oxidases involved in dye decolorization by the fungus Leptosphaerulina sp. BMC Biotechnol 15:74. doi:10. 1186/s12896-015-0192-2

Criquet S, Tagger S, Vogt G, Iacazio G, Le Petit J (1999) Laccase activity of forest litter. Soil Biol. Biochem. 31: 1239-1244. doi:10.1016 /S0038-0717(99)00038-3

Dave SR, Patel TL, Tipre DR (2015) Bacterial degradation of azo dyes containing wastes. In: Singh SN (ed) Microbial degradation of synthetic dyes in wastewaters. Springer, Lucknow, India, pp. 57-83

Dhiman K, Shirkot P (2015) Bioprospecting and molecular characterization of laccase producing bacteria from paper mills of Himachal Pradesh. Proc Natl Acad Sci India Sect B Biol Sci. doi:10. 1007/s40011-015-0541-X

Ding Z, Chen Y, Xu Z, Peng L, Xu G, Gu Z, Zhang L, Shi G, Zhang K (2014) Production and characterization of laccase from Pleurotus ferulae in submerged fermentation. Ann Microbiol 64:121-129. doi:10.1007/s13213-013-0640-y

Dorado J, Field JA, Almendros G, Sierra-Alvarez R (2001) Nitrogenremoval with protease as a method to improve the selective delignification of hemp steamwood by the white-rot fungus
Bjerkandera sp. strain B0S55. Appl Microbiol Biotechnol 57:2052011

Eggert C, Temp U, Dean JFD, Eriksson KEL (1996) A fungal metabolite mediates degradation of non-phenolic lignin structures and synthetic lignin by laccase. FEBS Lett 391(1-2):144-148

Eggert C, Temp U, Eriksson KEL (1997) Laccase is essential for lignin degradation by the white-rot fungus Pycnoporus cinnabarinus. FEBS Lett 407:89-92

Eisner T, Nowicki S, Goetz M, Meinwald J (1980) Red cochineal dye (carminic acid): its role in nature. Science 30 208(4447):1039-1042. doi:10.1126/science.208.4447.1039

El-Batal AI, ElKenawy NM, Yassin AS, Amin MA (2015) Laccase production by Pleurotus ostreatus and its application in synthesis of gold nanoparticles. Biotechnol Reports 5:31-39. doi:10.1016/j. btre.2014.11.001

Freeman HS, Hinks D, Esancy J (1996) Genotoxicity of azo dyes: bases and implications. In: Peters AT, Freeman HS (eds) Physico-chemical principles of color chemistry. Chapman \& Hall, Glasgow, UK, pp. 254-291

Galai S, Limam F, Marzouki MN (2009) A new Stenotrophomonas maltophilia strain producing laccase. Use in decolorization of synthetic dyes. Appl Biochem Biotechnol 158:416-431. doi:10.1007 /s12010-008-8369-y

Ghose TK (1987) Measurement of cellulase activities. Pure and Appl. Chem. 59: 257-268

Gupta R, Mehta G, Khasa YP, Kuhad RC (2011) Fungal delignification of lignocellulosic biomass improves the saccharification of cellulosics. Biodegradation 22:797-804. doi:10.1007/s10532-010-9404-6

Hallac BB, Sannigrahi P, Pu Y, Ray M, Murphy RJ, Ragauskas AJ (2009) Biomass characterization of Buddleja davidii: a potential feedstock for biofuel production. J Agric Food Chem 57:1275-1281

Hayat K, Gondal MA, Khaled MM, Ahmed S (2010) Kinetic study of laser-induced photocatalytic degradation of dye (alizarin yellow) from wastewater using nanostructured $\mathrm{ZnO}$. J Environ Sci Heal A 45(11):1413-1420. doi:10.1080/10934529.2010.500934

Hernández CA, Sandoval N, Mallerman J, García-Pérez JA, Farnet A-M, Perraud-Gaime I, Alarcón E (2015) Ethanol induction of laccase depends on nitrogen conditions of Pycnoporus sanguineus. Electron J Biotechnol 18:327-332. doi:10.1016/j.ejbt.2015.05.008

Hernández-Luna CE, Gutiérrez-Soto G, Salcedo-Martínez SM (2008) Screening for decolorizing basidiomycetes in México. World J Microbiol Biotechnol 24:465-473. doi:10.1007/s11274-007-9495-3

Hildenbrand S, Schmahl FW, Wodarz R, Kimmel R, Dartsch PC (1999) Azo dyes and carcinogenic aromatic amines in cell cultures. Int Árch Occup Environ Health 72:M52-M56

Howell C, Steenkjær AC, Goodell B, Jellison J (2009) Temporal changes in wood crystalline cellulose during degradation by brown rot fungi. Int Biodeg Biodeterior 63(4):414-419. doi:10.1016/j. ibiod.2008.11.009

Jolivalt C, Raynal A, Caminade E, Kokel B, Le Goffic F, Mougin C (1999) Transformation of $\mathrm{N}^{\prime}, \mathrm{N}^{\prime}$-dimethyl-N-(hydroxyphenyl)ureas by laccase from the white rot fungus Trametes versicolor. Appl Microbiol Biotechnol 51:676-681

Junghanns C, Parra R, Keshavarz T, Schlosser D (2008) Towards higher laccase activities produced by aquatic ascomycetous fungi through combination of elicitors and an alternative substrate. Eng Life Sci 8(3):277-285

Kanagaraj J, Senthilvelan T, Panda RC (2015) Degradation of azo-dyes by laccase: biological method to reduce pollution load in dye wastewater. Clean Technol Environ 17:1443-1456. doi:10.1007/s10098014-0869-6

Karp SG, Faraco V, Amore A, Birolo L, Giangrande C, Soccol VT, Pandey A, Soccol CR (2012) Characterization of laccase isoforms produced by Pleurotus ostreatus in solid state fermentation of sugarcane baggase. Bioresource Technol 114:735-739. doi:10.1016/j. biortech.2012.03.058 
Karp SG, Faraco V, Amore A, Letti LAJ, Soccol VT, Soccol CR (2015) Statistical optimization of laccase production and delignification of sugarcane bagasse by Pleurotus ostreatus in solid-state fermentation. BioMed Res Int . doi:10.1155/2015/181204181204

Khammuang S, Yuwa-amornpitak T, Svasti J, Sarnthima R (2013) Cooper induction of laccase by Lentinus polychrous under liquidstate fermentation. Biocatal Agri Biotechnol 2(4):357-362

Korniłłowicz-Kowalska T, Rybczyńska K (2014) Anthraquinone dyes decolorization capacity of anamorphic Bjerkandera adusta CCBAS 930 strain and its HRP-like negative mutants. World J Microbiol Biotechnol 30:1725-1736. doi:10.1007/s11274-014-1595-2

Kuhar F, Papinutti L (2014) Optimization of laccase production by two strains of Ganoderma lucidum using phenolic and metallic inducers. Rev Argent Microbiol 46(2):144-149. doi:10 1016 /S0325-7541(14)70063-X

Li X, Zhang J, Jiang Y, Hu M, Li S, Zhai Q (2013) Highly efficient biodecolorization/degradation of Congo red and alizarin yellow $\mathrm{R}$ by chloroperoxidase from Caldariomyces fumago: catalytic mechanism and degradation pathway. Ind Eng Chem Res 52(38):1357213579

Liang B, Yao Q, Cheng H, Gao S, Kong F, Cui D, Guo Y, Ren N, Wang A (2012) Enhanced degradation of azo dye alizarin yellow R in a combined process of iron-carbon microelectrolysis and aerobic bio-contact oxidation. Environ Sci Pollut Res 19:1385-1391. doi:10.1007/s11356-012-1137-0

Lomascolo A, Uzan-Boukhriz E, Herpoël-Gimbert E, Sigoillot J, LesageMeessen L (2011) Pecualiarities of Pycnoporus species for applications in biotechnology. Appl Microbiol Biotechnol 92:1129-1114. doi:10.1007/s00253-011-3596-5

Lui J, Cai Y, Liao X, Huang Q, Hao Z, Hu M, Zhang D (2012) Simultaneous laccase production and color removal by culturing fungus Pycnoporus sp. SYBC-L3 in a textile wastewater effluent supplemented with a lignocellulosic waste Phragmites australis. Bull Environ Contam Toxicol 89:269-273

Mann J, Markham JL, Peiris P, Spooner-Hart RN, Holford P, Nair NG (2015) Use of olive mill wastewater as a suitable substrate for the production of laccase by Cerrena consors. Int Biodeter Biodegr 99: 138-145. doi:10.1016/j.ibiod.2015.01.010

Masayuki T, Suzuki H, Watanabe D, Sakai K, Tanaka T (2005) Evaluation of pretreatment with Pleurotus ostreatus for enzymatic hydrolysis of rice straw. J Biosci Bioeng 100:637-642. doi:10. $1263 / \mathrm{jbb} .100 .637$

Massiot D, Fayon F, Capron M, King I, Le Calve S, Alonso B, Durand JO, Bujoli B, Gan Z, Hoatson G (2002) Modelling one- and twodimensional solid-state NMR spectra. Magn Reson Chem 40:70-76. doi: $10.1002 / \mathrm{mrc} .984$

Meza JC, Lomascolo A, Casalot L, Sigoillot J-C, Auria R (2005) Laccase production by Pycnoporus cinnabarinus grown on sugar-cane bagasse: influence of ethanol vapors as inducer. Process Biochem 40: 3365-3371. doi:10.1016/j.procbio.2005.03.004

Monteiro MC, De Carvalho MEA (1998) Pulp bleaching using laccase from Trametes versicolor under high temperature and alkaline conditions. Appl Biochem Biotechnol 70-72(1):983-993. doi:10. 1007/BF02920208

Papinutti L, Mouso N, Forchiassin F (2006) Removal and degradation of the fungicide dye malachite green from aqueous solution using the system wheat bran-Fomes screlodermeus. Enzym Microb Technol 39(4):848-853. doi:10.1016/j.enzmictec.2006.01.013

Park S, Baker JO, Himmel ME, Parrilla PA, Johnson DK (2010) Cellulose crystallinity index: measurement techniques and their impact on interpreting cellulase performance. Biotechnol Biofuels 3:10 http://www.biotechnologyforbiofuels.com/content/3/1/10. Accessed 2 May 2016

Pizzul L, del Pilar Castillo M, Stenström J (2009) Degradation of glyphosate and other pesticides by ligninolytic enzymes. Biodegradation 20:751-759. doi:10.1007/s10532-009-9263-1
Pointing SB, Vrijmoed LLP (2000) Decolorization of azo and triphenylmethane dyes by Pycnoporus sanguineus producing laccase as the sole phenoloxidase. World J Microb Biotechnol 16:317-318. doi:10.1023/A:1008959600680

Pointing SB, Jones EGB, Vrijmoed LLP (2000) Optimization of laccase production by Pycnoporus sanguineus in submerged liquid culture. Mycologia 92(1):139-144. doi:10.2307/3761458

Ramírez-Cavazos LI, Junghanns C, Ornelas-Soto N, Cárdenas-Chávez DL, Hernández-Luna C, Demarche P, Enaud E, García-Morales R, Agathos SN, Parra R (2014) Purification and characterization of two thermostable laccases from Pycnoporus sanguineus and potential role in degradation of endocrine disrupting chemicals. J Mol Catal B Enzym 108:32-42

Ramos LP (2003) The chemistry involved in the steam treatment of lignocellulosic matherials. Quim Nov. 26(6):863-871. doi:10. 1590/S0100-40422003000600015

Rico A, Rencoret J, del Río JC, Martínez AT, Gutiérrez A (2015) In-depth 2D NMR study of liginin modification during pretreatment of Eucalyptus wood with laccase and mediators. Bioenerg Res 8: 211-230. doi:10.1007/s12155-014-9505-x

Rodriguez E, Pickard MA, Vazquez-Duhalt R (1999) Industrial dye decolorization by laccases from ligninolytic fungi. Curr Microbiol 38:27-32

Ryu S-H, Cho M-K, Kim M, Jung S-M, Seo J-H (2013) Enhanced lignin biodegradation by a laccase-overexpressed white-rot fungus Polyporus brumalis in the pretreatment of wood chips. Appl Biochem Biotechnol 171:1525-1534. doi:10.1007/s12010-013-0412-y

Sen S-K, Raut S, Bandyopadhyaya P, Raut S (2016) Fungal decolouration and degradation of azo dyes: a review. Fungal Biol Rev 30(3):112-133

Songulashvili G, Elisashvili V, Wasser SP, Nevo E, Hadar Y (2006) Basidiomycetes laccase and manganese peroxidase activity in submerged fermentation of food industry wastes. Enzym Microb Technol 41:57-61

Songulashvili G, Spindler D, Jiménez-Tobón GA, Jaspers C, Kerns G, Penninckx MJ (2015) Production of a high level of laccase by submerged fermentation at 120-L scale of Cerrena unicolor C-139 grown on wheat bran. CR Biol 338:121-125. doi:10.1016/j. crvi.2014.12.001

StatSoft Inc (2004) STATISTICA for Windows. Manual version 7.0. StatSoft Inc. Tulsa, Oklahoma

Swamy J, Ramsay JA (1999) Effects of $\mathrm{Mn}^{2+}$ and $\mathrm{NH}_{4}{ }^{+}$concentrations on laccase and manganese peroxidase production and amaranth decoloration by Trametes versicolor. Appl Microbiol Biotechnol 51:391-396

Teerapatsakul C, Parra R, Bucke C, Chitradon L (2007) Improvement of laccase production from Ganoderma sp. KU-Alk4 by medium engineering. World J Microb Biot 23:1519-1527

Teerapatsakul C, Bucke C, Parra R, Keshavarz T, Chitradon L (2008) Dye decolourisation by laccase entrapped in copper alginate. World $\mathrm{J}$ Microb Biot 24:1367-1374

Usha KY, Praveen K, Reddy BR (2014) Enhanced production of ligninolytic enzymes by a mushroom Stereum ostrea. Biotechno Res Internat 2014:815495. doi:10.1155/2014/815495

Vanhulle S, Radman R, Parra R, Cui T, Bols C-M, Tron T, Sannia G, Keshavarz T (2007) Effect of mannan oligosaccharide elicitor and ferulic acid on enhancement of laccases production in liquid cultures of bacidiomycetes. Enzyme Microb Tech 40:1712-1718

Vargas M-C, Ramírez NE (2002) Phenol oxidation of petrol refinery wastewater catalyzed by laccase. CT \& F 2(3):23-30

Viswanath B, Rajesh B, Janardhan A, Kumar AP, Narasimha G (2014) Fungal laccases and their applications in bioremediation. Enzyme Res 163242:21

Yoshida M, Liu Y, Uchida S, Kawarada K, Ukagami Y, Ichinose H, Kaneko S, Fukuda K (2008) Effects of cellulose crystallinity, hemicellulose, and lignin on the enzymatic hydrolysis of Miscanthus 
sinensis to monosaccharides. Biosci Biotechnol Biochem 73(3): 805-810. doi:10.1271/bbb.70689

Younes SB, Bouallagui Z, Gargoubi A, Sayadi S (2011) Investigation of dyes degradation intermediates with Scytalidium thermophilum laccase. Eur Food Res Technol 233:751-758. doi:10.1007/s00217-011-1569-7

Yu Z, Gwak Y, Treasure T, Jameel H, Chang H, Park S (2014) Effect of lignin chemistry on the enzymatic hydrolysis of woody biomass. ChemSusChem 7:1942-1950. doi:10.1002/c ssc.201400042
Zheng Z, Li H, Li L, Shao W (2012) Biobleaching of wheat straw pulp with recombinant laccase from the hyperthermophilic Thermus thermophilus. Biotechnol Lett 34:541-547. doi:10.1007/s10529011-0796-0

Zilly A, Souza CGM, Barbosa-Tessmann IP, Peralta RM (2002) Decolorization of industrial dyes by a brasilian strain of Pleurotus pulmonarius producing laccase as the sole phenol-oxidazing enzyme. Folia Microbiol 47(3):273-277 